PENEMUAN KEMBALI Tropidonophis punctiventris (BOETTGER. 1895) (SERPENTES: COLUBRIDAE) SETELAH 116 TAHUN

\title{
REDISCOVERY OF THE HALMAHERA KEELBACK, Tropidonophis punctiventris (BOETTGER. 1895) (SERPENTES: COLUBRIDAE) AFTER 116 YEARS
}

\author{
Dadang Rahadian Subasli \\ Museum Zoologicum Bogoriense (MZB), Research Center for Biology, Indonesian Institute of \\ Science-LIPI; Jl. Raya Jakarta Bogor km 46, Cibinong, West Java 16911, Indonesia, \\ $+62218765056 /+62218765068$ \\ E-mail: d rsubasli@yahoo.com
}

(diterima Januari 2019, direvisi Mei 2019, disetujui Juli 2019)

\begin{abstract}
ABSTRAK
Tropidonophis punctiventris adalah ular endemik pulau Halmahera, Indonesia. Spesies ini sebelumnya dideskripsi pada tahun 1895 berdasarkan pada spesimen tunggal yang dikumpulkan pada tahun 1866 dari pulau Halmahera. Spesimen kedua dan ketiga dideterminasi berdasarkan spesimen yang dikoleksi pada tahun 1875 dan 1894 dari pulau yang sama. Setelah 116 tahun, spesimen keempat ditemukan dari Kao Rahai, Halmahera. Di sini kami memberikan data tentang morfologi T. punctiventris berdasarkan koleksi segar. Membahas temuan spesies ular langka dari Halmahera, yang mungkin disebabkan oleh populasi yang kecil, perilakunya yang tersembunyi, atau kurangnya penelitian intensif di daerah tersebut. Penemuan ini terus menggarisbawahi fakta bahwa Halmahera masih menyimpan keanekaragaman herpetologis yang belum terealisasi dan diperlukan penelitian lebih lanjut.
\end{abstract}

Kata kunci: Endemik, Halmahera, Kao rahai, morfologi, ular

\begin{abstract}
Halmahera Keelback, Tropidonophis punctiventris is endemic to the island of Halmahera, Indonesia. The species was previously described in 1895 based on a single specimens collected in 1866 from Halmahera island. The second and third specimen was determined based on the specimens collected in 1875 and 1894 from the same island. After 116 years, the fourth specimen was collected from Kao Rahai, Halmahera. Here we provide data on morphological of the Halmahera Keelback based on the fresh collection. We discuss the rarity finding of this snake species on Halmahera, which is possibly due to the small population, hidden behavior, or the lack of intensive research in the area. These discoveries continue to underscore the fact that Halmahera is still harbour unrealized herpetological diversity, further research is needed.
\end{abstract}

Keywords: Endemic, Halmahera, Kao rahai, morphology, snake

\section{INTRODUCTION}

Tropidonophis Jan, 1863 is a genus name of nineteen species of natricine snakes, which is distributed from southern Philippines, Moluccas, New Guinea and their adjacent islands to the east, Bismarck archipelagos and northern Australia (Malnate and Underwood 1988; Uetz et al., 2019). Several members of this genus have restricted distribution to the islands (e.g. T. anenigmaticus on Ferguson
Island; T. dendrophios on Basilan, Mindanao and Luzon; T. elongatus on Moluccas; $T$. halmahericus on Halmahera, Ternate, Bacan, Salawati; T. hypomelas on Duke of York Island; $T$. punctiventris on Halmahera, Northern Maluku Island; T. truncates on Salawati, Halmahera, Bacan, Ternate: Malnate \& Underwood, 1988).

Tropidonophis is a rare encountered snake in the field, during a Biological 
inventory in Halmahera in June 28, 2010 (Fig. 1) Riyanto \& Mulyadi collected a single specimen that morphologically refers to T. punctiventris. Tropidonophis punctiventris was described in 1895 based on the single specimen collected from Konorra, Halmahera island (Boettger, 1895). A collection of Tropidonophis from Halmahera Island in Genoa Museum (MSNG30112), that collected by Antonie Augustus Bruijn in 1875 was identified as T. picturatus (Schlegel 1837). This is a misidentification and actually it should be T. punctiventris (Petri \& Doria 2012). Subsequently, Malnate \& Underwood (1988) and Petri \& Doria (2012) reported the second and the third specimen of this species from old museum collections. Hereafter, we report discovery of the fourth specimen and provide additional informations on the morphology of this rare species.

\section{MATERIALS AND METHODS}

We examined single specimen of an adult male T. punctiventris (MZB.Ophi.4491), collected from Kao Rahai Camp, Nusa Jaya, South Wasile, East Halmahera Regency, North Maluku, Indonesia [0 $30^{\circ} 58.6^{\prime \prime} \mathrm{N} \quad 127^{\circ}$ $58^{\prime} 37.0^{\prime \prime E}$ ] on June 28, 2010. The specimen was deposited in herpetology collection, Museum Zoologicum Bogoriense (MZB), Zoology Division, Research Center for Biology, Indonesia Institute of Sciences in Cibinong, Bogor, West Java, Indonesia.

Body measurement: snout ventral length (SVL); tail length (TaL); total length (ToL), length of head, body and tail from the snout to tip off tail; the ratio of tail to total length (TaL/ ToL). Scalation: dorsal scales row (DSR); ventral plates $(\mathrm{VeP})$; subcaudal plates $(\mathrm{ScP})$; ventral plus subcaudal plates $(\mathrm{VeP}+\mathrm{ScP})$; ratio subcaudal plates/total ventral and subcaudal plates $(\mathrm{ScP} /(\mathrm{VeP}+\mathrm{ScP})$; nasal scales $(\mathrm{NaS})$; loreal scales (LoS); preocular scales (PrS); postocular scales (PoS); supralabial scales $(\mathrm{SuL})$; infralabial scales $(\mathrm{InL}), \mathrm{SuL}$ in contact with eye and Temporal scales formula. The number of ventral scales were counted according to Dowling (1951) and scalation were counted following Peters (1964). Body measurements were taken with callipers to the nearest 0.1 millimeter $(\mathrm{mm})$ and also using a meter stick. For the comparison purposes, we compared the recent collection with the holotype (SMF17195) and two non-type specimens (RMNH4804 and MSNG30112) of T. punctiventris from Petri \& Doria (2012), as well as the original description by Boettger (1895) and informations from (Malnate \& Underwood, 1988).

\section{RESULTS AND DISCUSSION}

Tropidonotus punctiventris Boettger 1895

\section{Synonyms:}

Tropidonotus punctiventris Boettger 1895: 129

(Holotype: SMF17195, male, Soa Konorra, Halmahera; collected by Prof. Dr. W.

Kükenthal's 1894); Boulenger 1896: 602; de Rooij 1917: 81.

Natrix punctiventris De Haas 1950: 543

Amphiesma punctiventris Malnate 1960: 50

Tropidonophis punctiventris Malnate \& Underwood 1988: 95

Tropidonophis punctiventris Walach et al. 2014: 751

\section{Description (based on MZB.Ophi.4491)}

Scalation and Measurements: Head length $16.1 \mathrm{~mm}$; snout-vent length $330 \mathrm{~mm}$; tail length $120 \mathrm{~mm}$; total length $450 \mathrm{~mm}$; diameter of the eye $3.0 \mathrm{~mm}$; eye-nostril distance $2.6 \mathrm{~mm}$; 
first chin shields length $4.0 \mathrm{~mm}$; second chin shields length $6.5 \mathrm{~mm}$. Ventrals 151; subcaudals 75 pairs; 15 dorsal scale rows at midbody; dorsal and uppercaudal scales are keeled, loreal is irregularly pentagonal. First mental and simphisial are separated by first infralabial. A single preventral is present. Supralabials $9\left(4^{\text {th }}, 5^{\text {th }}, 6^{\text {th }}\right.$ in contact with eye $)$; infralabials $9,1^{\text {st }}-5^{\text {th }}$ infralabials are in contact with first mental and $5^{\text {th }}-7^{\text {th }}$ infralabials are in contact with second mental. Pits on the head are present in the parietals, temporals and oculars scales and on the loreal only of the left side (Figure 2).

\section{Coloration (in preservative)}

Dorsal part of the head dark brownish with darker sutures between the internasal, prefrontal, frontal and parietal scales, the center of each parietals with bright blotches. Dorsal surface of body and tail dark brownish with distinct darker bands across the body and the tail. Sides of head dark brown as body coloration, except for supralabial region white with dark color on the upper sides, and infralabials white. Ventral side cream with dots (Figure 2).

\section{Comparison}

The pholidotic patterns were applied to the morphology comparisons between $T$. punctiventris male (MZB.Ophi.4491, SMF17195, MSNG30112,) and female (RMNH4804). Some of the similar characters not presented on summarize of comparison characters in Table 1 since there are no differences. In this case, all examined specimens having the same number in 15 rows of dorsal scales. Keeling of the caudal scales is as that on the dorsal scales.
The sum of these $(\mathrm{v}+\mathrm{sc})$ and the ratio of the subcaudals in the sum $(\mathrm{sc} / \mathrm{v}+\mathrm{sc})$ is 0.330 on the MZB.Ophi.4491, while 0.319 on the SMF17195, 0.338 on the RMNH4804, 0.329 on the MSNG30112. The loreal is slightly higher than long on the SMF17195, on the MZB.Ophi.4491, the height and length are subequal on the RMNH4804, and loreal is irregularly pentagonal on the MSNG30112. Counts for the oculars, temporals, labials and intergenials are given in Table 1. Infralabials are $7+3$ on the SMF17195, MZB.Ophi.4491, MSNG30112 and 7+2 on the RMNH4804. The posterior chinshields are separated for two-thirds of their length on the SMF17195 and fully separated on the MZB.Ophi.4491, on the RMNH4804, on the SMF17195 and on the MSNG30112 is unknown.

The top of the head is brown, spotted with dark brown. A pair of light parietal spots is present, in strong contrast to the broad dark area at the sides and posterior borders of the parietals for all individuals. Supralabials are light, anterior to the eye edged with black. A black stripe extends from the lower postocular to the corner of the mouth and onto the sides of the neck (to the level of the fifth ventral on the SMF17195, MZB.Ophi.4491, where it join the base of a dark nuchal crossband; to the level of the seventh ventral on RMNH 4804) The supralabials are clear with the upper part dark; first supralabials have brown lines on the MSNG30112.

The dorsum is brown with a dorsolateral series of light spots on the fourth to sixth scale rows which are less prominent on the posterior body. The light spots are bordered below by small dark spots and connected across the back by narrow black bars (MZB.Ophi.4491 
and SMF17195), or paired black spots (RMNH 4804). A series of four dark crossbands (each three scales long) is present on the neck (SMF17195); on RMNH 4804 bold dark spots are present. A narrow dark vertebral stripe and a suggestion of dark lateral stripes are present on the tail on the SMF17195, RMNH 4804, MZB.Ophi.4491, except on MSNG30112 unknown.

The anterior infralabials and lateral gulars of MZB.Ophi.4491 and SMF17195 are edged or spotted with black and of the RMNH 4804 are immaculate, except on the MSNG30112 unknown. The ventrals are light with brown spots arranged in irregular longitudinal series (five or six), the spots large, elongate and bolder on the posterior belly. A suffusion of light brown extends over the entire posterior venter. Each subcaudal bears a large, central, brown spots and brown stippling is present at the sides and the medial area in all specimens.

The male specimen (MZB.Ophi.4491) measures $450 \mathrm{~mm}$ in total length, the tail is $26.66 \%$ of that length. While, male specimen SMF17195 has $342 \mathrm{~mm}$ in total length, the tail is $25.5 \%$ of its length, and male specimen MSNG30112 measures $422 \mathrm{~mm}$ total length, the tail is $26.1 \%$ of that length. The female RMNH4804 have $324 \mathrm{~mm}$ TL, the tail about $27.7 \%$ of its total length. There is evidence of an umbilical scar on the RMNH4804 $\left(127^{\text {th }}\right.$ $129^{\text {th }}$ ventrals) and two small (ventrals), developing eggs are present (the larger egg measures $14 \mathrm{~mm} \times 3.5 \mathrm{~mm}$ ). Both examples are believed to be first year adults (Malnate \& Underwood 1988).

The SVL and TaL of Individual MZB.Ophi.4491 are $330 \mathrm{~mm}$ and $120 \mathrm{~mm}$
(Figure 2). A comparison to previous specimens (types and a non-type) showed no striking variations except in having longest total length, i.e., $450 \mathrm{~mm}$ (MZB.Ophi.4491) vs. $324 \mathrm{~mm}$ (RMNH4804), $342 \mathrm{~mm}$ (SMF17195) - 422 mm (MSNG30112).

\section{Habitat}

Terrestrial, fresh water, river side, substrate: soil, sand, gravel, stone; calm river rippling, the depth is not more than $30 \mathrm{~cm}$. Found at 08.00 local time in the secondary forests mixed with cultivated plants, about 339 $-430 \mathrm{~m}$ above sea level, it's a borders between the fields/gardens and secondary forests.

While there is no information on the specific habitat preferences of this species, other species in this genus are often found near to the freshwater in rainforests, open or cultivated country and towns (O'Shea 1996). It is not yet known whether this species has these extensive habitat requirements or no. The threat of this species is unknown.

The discovery of $T$. punctiventris was confirms its presence in the wild since it was last collected about 116 years ago and contributes more knowledge on its morphology. Several herpetological inventories have been conducted on Halmahera by Setiadi \& Hamidy (2006) and Subasli (2008), however no specimen of this species was found. Instead, Setiadi \& Hamidy (2006) only recorded T. halmahericus, the interaction and distribution pattern of these two species of Tropidonophis in a small island such as Halmahera is interesting topic for further research.

Due to the uncertainties biological informations of Tropidonophis punctiventris, 
the International Union Conservation Nations (IUCN) listed this species as data deficient (Vogel 2010). Further intensive research is needed to clarify, its abundance, ecology, and its range distribution. We do not have confidence to declare the rarity of this snake population existence do not have confidence to declare the rarity of $T$. punctiventris. It is probably due to the small population and hidden behavior of the species, or simply the lack of the intensive inventory research on Halmahera, especially on snakes.

\section{CONCLUSIONS}

The recent collected specimen of Tropidonophis from Halmahera was matched with the morphology of $T$. punctiventris, in addition, its the fourth specimen found so far. Many biological aspects of this species are still unknown, intensive research on this species is needed.

\section{ACKNOWLEDGEMENTS}

We thanks A. Riyanto, Mulyadi, E. A. Arida and A. Hamidy (MZB, Indonesia), for the snake collection, advices in the script and general support, and anonymous reviewers for general support, constructive comments and suggestions.

\section{REFERENCES}

Boettger, O. (1895). Liste der Amphibien und Batrachier des Insel Halmaheira nach den Sammlungen Prof. Dr. W. Kükenthal's. Zoologischer Anzeiger 18: 116-121, 129-138.

De Rooij, N. (1917). The Reptiles of the
Indo-Australian Archipelago. II. Ophidia. E. J. Brill, Leiden. xiv +334.

Dowling, H. G. (1951). A proposed standar system of counting ventrals in snakes. British Journal of Herpetology, 1(5), 97 $-99$.

Malnate, E. V. \& Underwood, G., (1988). Australian natricine snakes of the genus Tropidonophis - Proceedings of the Akademy of Natural Sciences of Philadelphia, 140 (1), 59-201.

O'Shea, M., 1996. A Guide to the Snakes of Papua New Guinea. Independent Publishing Group Pty Ltd. Port Moresby, PNG. 239.

Peters, W. \& Doria, G. (1878). Catalogo dei Rettili e dei Batraci raccolti da O. Beccari, L. M. d'Albertis A. A. Bruijn nella sotto-regione Austro-Malese. Annali del Museo civico di storia naturale di Genova, 13, 323-450.

Peters, J. A. (1964). Dictionary of Herpetology. Hafter Publ. Co., NY \& London.

Petri, M. \& Doria, G. (2012). Tropidonophis punctiventris (Boettger, 1895): Description of the Third Known Specimen (Serpentes, Colubridae, Natricinae). Annali del Museo civico di storia naturale di Genova, VIII - N. 377.

Setiadi, M. I. \& Hamidy, A. 2006. Jenis-Jenis Herpetofauna di Pulau Halmahera. Kerjasama antara Pusat Studi Biodiversitas dan Konservasi Universitas Indonesia dan Museum Zoologicum Bogoriense, Puslit Biologi Lembaga Ilmu Pengetahuan Indonesia. 117.

Subasli, D. R. (2008). Survei herpetofauna Weda Bay Halmahera Tengah - Maluku Utara. 34, Laporan Perjalanan. Unpublished.

Uetz, P. \& Hallermann, J. (2019). The Reptile Database [online]. Diambil dari http:// www.reptile-database.org [19 December 2019].

Vogel, G., (2010). Tropidonophis punctiventris. In: IUCN Red List of Threatened Species. Version 2011.2. Diambil dari hhtp://www.iucnredlist.org [09 Juli 2017]. 